and chest pain simulating prolonged angina or a myocardial infarction which occurred about 30 minutes after taking the drug. These symptoms lasted for up to three hours and did not recur when the drug was withdrawn. We considered the chest pain to be a direct effect of nifedipine treatment. Nifedipine increases the myocardial blood supply and reduces coronary sinus lactate concentrations. ${ }^{3}$ It also tends to increase cardiac output and heart rate and to reduce peripheral resistance. ${ }^{45}$ These effects possibly caused the cardiac pain in our patients. We suggest that patients starting treatment with nifedipine should be warned to discontinue the drug immediately if they experience these side effects.

${ }^{1}$ Kenmure, A C F, and Scruton, J H, paper presented at 3rd International Adalat Symposium, Rio de Janeiro, 1975.

2 McIllwraith, G, in New" Therapy of Ischaemic Heart Disease, ed W Lochner, W Braasch, G Knoneberg. Berlin, Springer-Verlag, 1976.

${ }^{3}$ Schaefer, J, et al, paper presented at 1st International Nifedipine Adalat Symposium, Tokyo, 1975.

${ }^{4}$ Lichtlen, P, paper presented at 1st International Nifedipine Adalat Symposium, Tokyo, 1975.

${ }^{5}$ Schwarzkopf, H J, et al, Arzneimittel-Forsch, 1972, 22, 367.

(Accepted 3 March 1978)

St Woolos Hospital, Newport, Gwent

A G JARIWALLA, MB, MRCP, senior medical registrar

E G ANDERSON, MD, FRCP, consultant physician

\section{Visual hallucinations and illusions with propranolol}

Disorders of visual perception are known to occur, in the absence of confusion, in hypertensive patients treated with $\beta$-adrenoceptor blockers including propranolol, sotalol, and pindolol. This study, in which patients treated with propranolol were subjected to a semistructured interview, shows a much higher incidence $(17.5 \%)$ than has been recorded in reviews of clinical trials $\left(0 \cdot 3-0 \cdot 6^{\circ}\right) .^{1}$

\section{Patients, methods, and results}

A total of 115 patients attending a hypertension clinic were treated with propranolol with or without other antihypertensives: 77 patients were taking propranolol either alone or with diuretics. Of these 63 (27 women; 36 men) were systematically studied by a semi-structured interview including a check list for 55 psychological and somatic symptoms. The average age of these patients was 51 years (range 25-70 years), and their average daily dose of propranolol was $200 \mathrm{mg}$ (range $60-640 \mathrm{mg}$ ).

Eleven of these patients (see table) were found to have recurrent visual perceptual disorders-an incidence of $17 \cdot 5 \%$. (The lowest possible incidence for the whole group of 77, given that no other patient had similar symptoms, would be $14.3 \%$.) Visual hallucinations were recurrent in six patients but had occurred as isolated instances in a further two, who thought they might be dreaming. Although lacking in colour, hallucinations were so vivid that two patients were frightened: two patients, however, were aware that their hallucinations lacked reality. Recurrent visual illusions-for example, furniture and clothes appearing to change into animals and people-occurred in 10 patients; distortions of spatial allocation and perspective also occurred with displacement of furniture or opening of doors. The following cases illustrate the type of disorders experienced.

Case 1-This man saw a dead body in a lighted niche by his bed turning towards him; his pillow was made of spiders. Furniture and doors moved, opening on to strange rooms.

Case 2-This patient repeatedly saw a scarred man coming to his bedside, and would lash out at him.

Case 3-A helmeted coalminer appeared at the window of this patient. His clothes turned into people sitting on chairs.

Case 4-This man saw his alarm clock turn into an owl and his dressinggown into a man, who came to his bedside.

All episodes of visual perceptual disorder occurred in either hypnagogic or hypnopompic states and were abolished by complete wakefulness. During interviews all patients were in clear consciousness with no evidence of psychiatric abnormality, although two complained of drowsiness and mild dysphoria. The onset of hallucinations occurred in four patients within a week of an increase in dose. Hallucinations stopped a few days after the drug was withdrawn in four patients who found them intolerable. The four patients who had the most vivid hallucinations regularly consumed alcohol. Withdrawal from the drug, but not from alcohol, abolished the symptoms.

\section{Comment}

The results of this study, in which symptoms were systematically sought in a semi-structured interview, show that it is important to realise that visual perceptual disorders may occur in patients receiving propranolol in modest doses (average dose $254 \mathrm{mg}$ daily) for hypertension. Patients may not complain of these spontaneously because they fail to connect the symptoms with the drug and may be embarrassed to discuss possible mental illness or excessive use of alcohol. They may also attribute hallucinations to dreaming, and some of the nightmares and bizarre dreams described as side effects ${ }^{1}{ }^{2}$ may in fact be hypnagogic hallucinations.

The reported low incidence of visual hallucinations has been offered as evidence that propranolol has little central action in man, ${ }^{3}$ although it is now known that it crosses the blood-brain barrier and is concentrated in the brain of man. ${ }^{4}$ Recent work on the treatment of schizophrenia with propranolol," however, suggests that the drug has central psychotropic properties. The present findings add further support for this, and show that central effects may develop at doses commonly used to treat hypertension.

I am indebted to Dr B F Robinson, in whose clinic this work was done and whose help was invaluable. I thank Professor J P Watson and Professor E S Paykel for their help. This work was supported by a grant from ICI Limited.

${ }^{1}$ Stephen, S A, American fournal of Cardiology, 1966, 18, 463.

2 Conway, J, Modern Trends in Cardiology, 1975, 3, 376.

${ }^{3}$ Lancet, 1976, 2, 611 .

${ }^{4}$ Myers, M G, et al, fournal of Pharmacology and Experimental Therapeutics, 1975, 192, 327

${ }^{5}$ Yorkston, N J, et al, Lancet, 1977, 2, 575.

(Accepted 22 March 1978)

Hypertension Clinic, St George's Hospital, London SW17 0QT

RUTH FLEMINGER, MB, MRCPSYCH, honorary research assistant

Visual hallucinations and illusions: side effects of propranolol

\begin{tabular}{|c|c|c|c|c|c|c|c|}
\hline $\begin{array}{l}\text { Case } \\
\text { No }\end{array}$ & $\begin{array}{l}\text { Age and } \\
\text { sex }\end{array}$ & $\begin{array}{l}\text { Critical dose of } \\
\text { propranolol } \\
\text { (mg/day) } \\
\text { (previous dose) }\end{array}$ & $\begin{array}{c}\text { Symptoms } \\
\text { intolerable, } \\
\text { necessitating } \\
\text { withdrawal }\end{array}$ & Alcohol* & $\begin{array}{l}\text { Relation of } \\
\text { disorders } \\
\text { to sleep }\end{array}$ & Hallucinations & Illusions \\
\hline $\begin{array}{r}1 \\
2 \\
3 \\
4 \\
5 \\
6 \\
7 \\
8 \\
9 \\
10 \\
11\end{array}$ & $\begin{array}{ll}55 & M \\
38 & M \\
37 & M \\
43 & M \\
60 & M \\
42 & M \\
59 & M \\
57 & F \\
52 & M \\
44 & M \\
61 & F\end{array}$ & $\begin{array}{l}240(120) \\
240(120) \\
320 \\
160(80) \\
160 \\
320(160) \\
320(160) \\
320(240) \\
320 \\
320(150) \\
80\end{array}$ & $\begin{array}{l}\text { Yes } \\
\text { Yes } \\
\text { Yes } \\
\text { Yes }\end{array}$ & $\begin{array}{c}++ \\
++ \\
+++ \\
++ \\
+ \\
+ \\
++ \\
+ \\
\text { Unknown } \\
+\end{array}$ & $\begin{array}{l}\text { After } \\
\text { Before } \\
\text { After } \\
\text { After } \\
\text { After } \\
\text { After } \\
\text { Before } \\
\text { After } \\
\text { Before } \\
\text { After } \\
\text { After }\end{array}$ & $\begin{array}{l}\text { Yes } \\
\text { Yes } \\
\text { Yes } \\
\text { Yes } \\
\text { Yes } \\
\text { No } \\
\text { No } \\
\text { No } \\
\text { Yes } \\
\text { No } \\
\text { No }\end{array}$ & $\begin{array}{l}\text { Yes } \\
\text { Yes } \\
\text { Yes } \\
\text { Yes } \\
\text { No } \\
\text { Yes } \\
\text { Yes } \\
\text { Yes } \\
\text { Yes } \\
\text { Yes } \\
\text { Yes }\end{array}$ \\
\hline
\end{tabular}

